\title{
Identifying Characteristics of Verticillium Wilt Suppressiveness in Olive Mill Composts
}

Manuel Avilés and Celia Borrero, ${ }^{\dagger}$ Dept. Ciencias Agroforestales, Escuela Técnica Superior de Ingeniería Agronómica, Universidad de Sevilla, Ctra. Utrera km 1, 41013 Sevilla, Spain

\begin{abstract}
The aims of this study were to assess the potential suppressive effects of different olive mill composts on Verticillium wilt and to elucidate the suppressive mechanisms. To this end, four olive mill composts from different crop areas with two maturation levels were selected. After conducting the Verticillium wilt bioassays in cotton, the suppressive effect was observed in only one compost. Compost maturation level did not affect disease development. The standardized area under the disease progress curve and microsclerotia concentration were associated with low API-ZYM enzymatic diversity, $\beta$-glucosidase activity, $\mathrm{pH}$, and high electrical conductivity (EC). To assess the nature of suppressiveness in the suppressive compost, additional bioassays were performed with three

treated compost-amended growing media ( $\mathrm{N}$-supplemented, autoclaved, and heat treated at $60^{\circ} \mathrm{C}$ for 6 days). Suppressiveness was partially reduced with heat treatments, where $\mathrm{N}$-acetyl- $\beta$-glucosaminidase activity disappeared. In this compost, high oligotrophic actinomycete populations were associated with disease reduction. Therefore, plant growth media amended with different olive mill composts do not always show suppressiveness against Verticillium wilt. Enzymatic diversity, $\beta$-glucosidase activity, $\mathrm{pH}$, and $\mathrm{EC}$ may be sufficient to predict where olive mill compost plant growth media will be effective in reducing Verticillium wilt and microsclerotia concentration. General and specific suppressiveness are involved in the mechanism of compost suppression.
\end{abstract}

Verticillium wilt is currently considered a major soilborne disease threatening many crops worldwide and unfortunately, there are limited chemical control options (López-Escudero and Mercado-Blanco 2011). In Andalusia, southern Spain, this disease causes severe problems in both young and old olive orchards and has spread to all the other major olive-growing areas in Spain (Jiménez-Díaz et al. 2012). Verticillium wilt of olive and cotton are very similar pathosystems. Verticillium dahliae isolates infecting both crops are traditionally classified into defoliating and nondefoliating pathotypes. Thus, an isolate recovered from cotton or olive displays cross-virulence in both crops (López-Escudero and Mercado-Blanco 2011). The primary forms of $V$. dahliae dispersion are the establishment of new olive orchards on former cotton fields and pathogen infection of susceptible crops nearby (Jiménez-Díaz et al. 2012; López-Escudero and Mercado-Blanco 2011). Preventive and/or biological control strategies must be developed to reduce this disease.

Spain is the main olive fruit and olive oil producer in the world, accounting for nearly $40 \%$ of production (FAO 2015). Andalusia is the largest olive cultivation area $(61 \%)$ and accounts for $83 \%$ of the total national production of olives for oil production (Ministerio de Agricultura Alimentación y Medio Ambiente 2015). Nowadays, a two-phase centrifugation system is the most commonly used olive oil extraction method in Spain. This system generates olive oil plus a semisolid waste, known as olive mill waste or alperujo (Morillo et al. 2009), which represents $90 \%$ of olive weight (Ministerio de Medio Ambiente 2007).

Olive mill waste is not recommended for use as an organic soil amendment in olive orchards due to its acidic $\mathrm{pH}$, potential phytotoxicity, and the possibility of soil contamination with $V$. dahliae (Jiménez-Díaz

${ }^{\dagger}$ Corresponding author. E-mail: cborrero@us.es

*The $\boldsymbol{e}$-Xtra logo stands for "electronic extra" and indicates that one supplementary table and two supplementary figures are published online.

Accepted for publication 17 May 2017.

() 2017 The American Phytopathological Society et al. 2012; Morillo et al. 2009). There is increasing interest in composting as a sustainable strategy to recycle this waste for agricultural purposes. To achieve this, due to its semisolid consistency and low porosity, the residue should be mixed with bulking agents (Chowdhury et al. 2013; Morillo et al. 2009). The type of bulking agent, ratio of olive mill waste to bulking agent, and composting method used may vary. Many types of bulking agents exist, including olive leaves, cotton gin trash, rice hulls, sheep manure, and grape stalks (Alfano et al. 2011, 2009; Borrero et al. 2009; Cayuela et al. 2008; Moreno et al. 2016). After composting, nonphytotoxic organic matter-rich materials free of pathogens are obtained (Morillo et al. 2009; Principi et al. 2001), and these materials are suitable for use as organic soil amendments and plant growing media (Caballero et al. 2009). It is particularly significant that composting can be an efficient way of reducing $V$. dahliae propagules (Noble and Roberts 2004).

Some composts have been shown to have suppressive effects on different phytopathogens, including $V$. dahliae, when added to plant growth media or soils (Bonanomi et al. 2010; Litterick et al. 2004; Noble and Coventry 2005). In particular, the suppressive effects of some olive mill composts on Verticillium wilt disease have been observed in tomato (Alfano et al. 2011; Arriagada et al. 2012; Vitullo et al. 2013), eggplant (Malandraki et al. 2008; Markakis et al. 2008; Papasotiriou et al. 2013), and cotton (Castaño and Avilés 2013). Also, olive mill extracts can inhibit $V$. dahliae growth in agar culture media (Alfano et al. 2011; Arriagada et al. 2012; Lima et al. 2008) and reduce microsclerotia concentration in soils or plant growth media (Castaño and Avilés 2013; Lima et al. 2008; Vitullo et al. 2013).

Historically, compost suppressiveness has been divided into two major categories: general and specific. General suppression is related to the sum of the activities of the overall microbial biomass, and specific suppression is a consequence of the activities of a reduced number of microorganism populations (Alfano et al. 2011; Avilés et al. 2011; Hoitink and Boehm 1999; Stone et al. 2004). The abiotic environment (aeration, $\mathrm{pH}$, mineral composition, etc.) is also relevant in explaining suppressiveness (Avilés et al. 2011; Termorshuizen and Jeger 2008). If suppressiveness is eliminated by pasteurization, biocides, or harsher treatments like autoclaving, then the suppressiveness is due to biological factors (Weller et al. 2002). In contrast to specific suppression, general suppression is usually recovered 
after sterilization due to the rapid colonization of microorganisms (Termorshuizen and Jeger 2008). Another characteristic of general suppression is that the number of pathogen propagules does not decline rapidly in suppressive media (Hoitink et al. 1993).

$V$. dahliae can be transported long distances in infected planting stock and/or infested potting soil, and thus can be introduced in pathogen-free olive-growing areas. The spread of the pathogen can be further enhanced if olive nurseries are established in $V$. dahliaeinfested areas and the asymptomatic host plants distributed across the olive production region (Jiménez-Díaz et al. 2012). Compost application in the field can be expensive due to the large quantities required; however, its application in nurseries is easier and more practical than in large-scale field production (Malandraki et al. 2008). Thus, olive mill compost obtained after a strong thermophilic phase followed by extensive recolonization of mesophilic microorganisms would be free of pathogens and could confer Verticillium wilt suppressiveness to the plant growth media used in olive nurseries, even after transplanting in open fields (Hoitink and Boehm 1999; Noble and Roberts 2004). Additionally, the incorporation of olive mill compost in plant growth media would give value to this residue.

The first objective of this work was to study the potential suppressive effects of different olive mill composts on Verticillium wilt. For this purpose, commercial olive mill composts obtained from different sources and having different maturation levels were studied. The second objective was to elucidate the primary mechanisms explaining these suppressive effects.

\section{Materials and Methods}

Olive mill waste composts and plant growth media. Four olive mill composts were obtained from four companies in different olive production areas in Andalusia. These composts encompassed the usual variability found in these types of products (i.e., bulk density, $\mathrm{pH}$, organic matter, etc.), and were named $\mathrm{OC} 1, \mathrm{OC} 2, \mathrm{OC} 3$, and OC4. The composts represented two maturation levels, with curing phases of either 4 months or 1 year, and each contained source materials specific to each company (Supplementary Table S1).

For each type of compost and maturation level, two subsamples were collected and assessed for a number of properties including: bulk density (BD) according to De Boodt et al. (1974), organic matter following the European Standard (European Committee for Standardization 2011), total $\mathrm{C}$ and $\mathrm{N}$ by the Dumas method described in UNE-EN 13039 (AENOR 2002), electrical conductivity (EC), and $\mathrm{pH}$. The latter two properties were determined in 1:5 v/v compost/water extracts.

To reduce salinity, the composts were flushed with three volumes of water per volume of compost (Sullivan and Miller 2001) and then mixed at a ratio of one part compost to two parts peat substrate. The commercial peat substrate used (Kekkilä Iberia S.L., Valencia, Spain) was composed of a mixture of light and brown peat (50:50 $\mathrm{v} / \mathrm{v}$ ) slightly amended with an NPK fertilizer and $\mathrm{pH}$ corrected. These plant growth media formulated with the different composts were designated OC1-GM, OC2-GM, OC3-GM, and OC4-GM and compared with peat substrate as the standard plant growth medium (control). The peat used as the control was enriched with $0.17 \mathrm{~g} /$ liter of $\mathrm{NH}_{4} \mathrm{H}_{2} \mathrm{PO}_{4}\left(12 \% \mathrm{~N}\right.$ and $61 \% \mathrm{P}_{2} \mathrm{O}_{5}$, Fertiberia, Madrid, Spain), $0.52 \mathrm{~g} /$ liter of $\mathrm{NH}_{4} \mathrm{NO}_{3}$ (33.5\% N, Fertiberia, Madrid, Spain), and $6.15 \mathrm{~g} /$ liter of $\mathrm{K}_{2} \mathrm{SO}_{4}\left(50 \% \mathrm{~K}_{2} \mathrm{O}\right.$, Compo Agricultura S.L., Barcelona, Spain) in order to achieve nutrient availability comparable to the other compost amended plant growth media. To standardize the initial conditions, all plant growth media were incubated in 7 -liter bags at $25^{\circ} \mathrm{C}$ for 14 days (Inbar et al. 1991) with $40 \%$ water by volume.

Olive mill compost bioassays. Four bioassays were performed to study the potential suppressive effects of the different compost amended plant growth media on Verticillium wilt. Two bioassays were performed with short-matured composts (composts matured for 4 months) and two with long-matured composts (composts matured for 1 year). Each bioassay was arranged in a randomized block design with 4 compost types $\times 3$ blocks $\times 5$ inoculated pots (replications) for a total of 60 pots. In addition, in each bioassay, three pots of each plant growth medium were not inoculated and served as the negative check in order to evaluate compost effects on plant growth in the absence of disease, resulting in an additional 36 control pots for a total of 96 pots per bioassay.

The suppressive capacity of olive mill compost against Verticillium wilt was evaluated in cotton plants cv. Carlota (Eurosemillas, S.A., Córdoba, Spain). Cotton bioassays are faster than those for olive, and facilitate standardized plant development. The similarity of both cotton and olive pathosystems makes this host substitution possible (López-Escudero and Mercado-Blanco 2011).

Each replication consisted of one 0.8-liter pot with one cotton plant derived from three seeds that were pregerminated, sown in individual pots, and thinned after 1 week. The plants were grown in a growth chamber set at $25^{\circ} \mathrm{C}$ (day) and $23^{\circ} \mathrm{C}$ (night), with $14 \mathrm{~h}$ light, $10 \mathrm{~h}$ dark, and drip-irrigated. The plants were fertilized with $1 \mathrm{~g} / \mathrm{liter}$ of Peters foliar feed 27-15-12 (N-P-K, Scotts, Heerlen, The Netherlands) on a weekly basis.

An isolate of V. dahliae defoliant pathotype (isolate V25) obtained from a diseased olive tree was used as the pathogen. The isolate was grown on PDA with streptomycin sulfate $(0.05 \mathrm{~g} / \mathrm{liter})$. The plates were scraped with water, filtered through cheesecloth, and the conidia were counted with a hemocytometer. Twelve days after sowing, each pot was placed in a plastic bag which, in turn, was inserted into an empty pot. The inoculum was adjusted to $5 \times 10^{6}$ conidia per $\mathrm{ml}$ of solution based on previous preliminary assays. A $400-\mathrm{ml}$ aliquot of inoculum solution was added to each pot as a drench, and allowed to infuse through the growth media for $1 \mathrm{~h}$. The pots were then drained by removing the plastic bag from around each pot and incubated at $90 \%$ relative humidity for 3 days in the dark. The controls were treated in the same way using water.

Disease severity was scored twice a week based on a symptom severity scale where: $0=$ asymptomatic plants; $1=$ slightly symptomatic plants ( 1 to $33 \%$ of leaves affected); $2=$ moderately symptomatic plants (34 to $66 \%$ of leaves affected); $3=$ severely symptomatic plants (67 to $99 \%$ of leaves affected but plants not dead); and $4=$ dead plants (Bejarano-Alcázar et al. 1995). Each score was converted to the midpoint of the corresponding disease severity range prior to using parametric analyses. The standardized area under the disease progress curve (AUDPC) per pot was calculated from the disease severity values by the trapezoidal integration method between the onset of symptoms and the ending time of the bioassay divided by the total duration (days) of the epidemic in each bioassay, in order to compare the various bioassays in which the duration of the epidemic varied (Campbell and Madden 1990). The disease severity at the end of bioassays and the AUDPC data were used for further analyses.

The bioassays ended when the majority of the inoculated plants grown in the unamended peat media were dead (about 2 months). At the end of the bioassays, fresh shoot weight was recorded, as well as dry weight after drying in a forced-air oven until a constant weight was obtained.

In order to quantify the concentration of $V$. dahliae microsclerotia in the rhizosphere at the end of the bioassays, rhizospheric and nonrhizospheric growth media were separated following Dhingra and Sinclair (1995). Rhizosphere samples from five pots for each compost amendment, block, and bioassay were collected, combined, crushed, mixed, and air-dried for 4 weeks. For wet sieving analysis (Harris et al. 1993), $25 \mathrm{~g}$ of each plant growth medium was suspended in $250 \mathrm{ml}$ of distilled water and shaken for $1 \mathrm{~h}$ at $270 \mathrm{rpm}$ in an orbital shaker. The suspension was then washed through nested 150 and $36 \mu \mathrm{m}$ sieves with tap water, and the material on the $36 \mu \mathrm{m}$ sieve was recovered and made up to $100 \mathrm{ml}$ with distilled water. Aliquots of 1-ml suspension were plated on modified soil extract agar medium (Harris et al. 1993) with 10 plates per sample. The plates were incubated at $22^{\circ} \mathrm{C}$ in the dark for 2 weeks and the plant growth medium residues were washed away with distilled water. The plates were then dried and incubated for an additional 2 to 3 weeks, after which the $V$. dahliae colonies were counted.

Physical and chemical properties of the plant growth media. Bulk density, $\mathrm{pH}$, and $\mathrm{EC}$ of the growth media were measured on subsamples collected from each of the formulated and incubated plant growth media used in each of the bioassays. Electrical conductivity and $\mathrm{pH}$ were measured in 1:5 v/v water extracts, according to 
Handreck and Black (2002), in two samples for each plant growth medium; block, bioassay, and mean values per block were used for statistical analysis. Bulk density was also determined for each of these samples, following De Boodt et al. (1974).

To assess phytotoxicity, a seedling growth test was performed directly in the plant growth media. Prior to conducting the bioassays, three bags (replications) per plant growth medium were prepared and incubated for 11 days, under the conditions previously described, and three subsamples collected from each bag were tested for phytotoxicity following the modified method of Ortega et al. (1996). For this test, $20 \mathrm{ml}$ volume sample of the plant growth media was placed in $9 \mathrm{~cm}$ diameter Petri dishes, wetted with distilled water, and 10 lettuce (Lactuca sativa) seeds were sown in each dish (3 Petri dishes per plant growth medium and bag). After sowing, the dishes were placed in an incubator at $20^{\circ} \mathrm{C}$ in the dark for 1 week. Subsequently, the germinated seeds were counted $(\mathrm{G})$ and radicle growth $(\mathrm{L})$ measured. The germination index (GI) was calculated according to the formula $\mathrm{GI}=\mathrm{G} / \mathrm{Go} \times \mathrm{L} / \mathrm{Lo} \times 100$, where Go and Lo are the germination percentage and radicle growth of the control, respectively (Zucconi et al. 1985). The germination index can assess both low toxicity, which mainly affects root growth, and high toxicity, which affects seed germination (Selim et al. 2012).

A fungitoxicity assay was performed to detect inhibition of $V$. dahliae mycelial growth in each plant growth medium amended with either short- and long-matured compost. Subsamples collected from the same bags used for phytotoxicity measurement were dried at room temperature, milled, and sieved at $250 \mu \mathrm{m}$. As described by Kokalis-Burelle and Rodríguez-Kábana (1994), the culture media were prepared with each milled plant growth medium by suspending $100 \mathrm{~g}$ of this material and $15 \mathrm{~g}$ of agar in 1 liter of deionized water. Control plates without the plant growth medium (water agar) were also prepared. The media were autoclaved at $105^{\circ} \mathrm{C}$ for $30 \mathrm{~min}$. The plates were then inoculated with a 5-mm-diameter plug of $V$. dahliae taken from the leading edge of a 6-day-old culture. Twenty replicate plates per treatment and replication $(n=60)$ were incubated at $25^{\circ} \mathrm{C}$ in the dark. After 20 days, radial fungal growth was evaluated and the percentage of growth inhibition (PGI) calculated as follows:

$$
\begin{aligned}
\text { PGI }= & (\text { Growth in control }- \text { Growth in treatment }) \\
& \times 100 / \text { Growth in control }
\end{aligned}
$$

Biological characteristics of the plant growth media. Biological analyses were performed on subsamples collected from incubated growth media at the beginning of each bioassay prior to being divided into the pots (three bags [replications] per plant growth medium). The enzymatic activities in the plant growth media were determined using the API-ZYM system (BioMereux SA, Marcy-l'Etoile, France). With the API-ZYM system, semiquantitative evaluations were performed on the activities of 19 hydrolyticenzymes (alkaline phosphatase, esterase [C4], esterase-lipase [C8], lipase [C14], leucine arylamidase, valine arylamidase, cistine arylamidase, trypsin, $\alpha$-chymotripsin, acid phosphatase, Naphtol-AS-BI-phosphohydrolase; $\alpha$-galactosidase, $\beta$-galactosidase, $\beta$-glucuronidase, $\alpha$-glucosidase, $\beta$-glucosidase, $\mathrm{N}$-acetil- $\beta$-glucosamidase, $\alpha$-mannosidase, and $\alpha$-fucosidase) (Ranalli et al. 2001). Using a sterile Pasteur pipette, each gallery was inoculated with two drops of $10 \times$ diluted suspension of $10 \mathrm{~g}$ of plant growth medium in $90 \mathrm{ml}$ of sterile saline solution $(8 \mathrm{~g} /$ liter $\mathrm{NaCl}$, w/v) and shaken at $150 \mathrm{rpm}$ for $30 \mathrm{~min}$. After incubation at $28^{\circ} \mathrm{C}$ for $4 \mathrm{~h}$, the galleries were activated by adding one drop of Reagent ZYM A and Reagent ZYM B (BioMereux SA, Marcy-l'Etoile, France), and after $5 \mathrm{~min}$ at room temperature, a numerical value of 1 to 5 was assigned to each microcupule according to the colorimetric standard table provided by the manufacturer. For each API-ZYM strip, the hydrolysis of each enzyme substrate was divided by average enzyme hydrolysis of the strip. API-ZYM enzyme activities were used to determine Shannon's diversity index (Zak et al. 1994).

$\beta$-glucosidase activity was also estimated for the plant growth media with a colorimetric determination following Bandick and Dick (1999) with minor modifications, as described by Borrero et al. (2009). Four samples were analyzed for each plant growth medium per bioassay block. The mean values per block were used for statistical analysis.
As an indicator of microbial biomass, the oxygen uptake rate (OUR) was measured with the OxiTop Control OC110 system (WTW, Weiheim, Germany). The plant growth medium (25 g) was placed in a respirometer jar and incubated for 5 days at $20^{\circ} \mathrm{C}$. The purpose of this operation was to measure the decrease in pressure in the closed system due to absorption of the $\mathrm{CO}_{2}$ released in $\mathrm{NaOH}$ when the temperature was regulated in the incubator. Oxygen consumption can be calculated from the pressure difference (Castaño and Avilés 2013). Three samples were analyzed for each plant growth medium per bioassay block. The mean values per block were used for statistical analysis.

Bioassays to elucidate the mechanism of compost suppression. After conducting the four bioassays with the four compost types and the two maturation levels, only OC3-GM was shown to be suppressive to cotton Verticillium wilt. Three new bioassays were therefore performed to elucidate the way in which compost OC3 promoted suppressiveness. These bioassays included five treatments: untreated OC3-GM formulated with short matured OC3 compost (OC3s-GM), OC3s-GM supplemented with $0.52 \mathrm{~g} /$ liter $\mathrm{NH}_{4} \mathrm{NO}_{3}(33.5 \% \mathrm{~N}$, Fertiberia, Madrid, Spain) (OC3s-GM-N), OC3s-GM heat treated at $60^{\circ} \mathrm{C}$ for 6 days (OC3s-GM-H), OC3s-GM autoclaved at $120^{\circ} \mathrm{C}$ for $1 \mathrm{~h}$ at $1.2 \mathrm{~atm}$ on two consecutive days (OC3s-GM-A), and a peat control (peat) fertilized as previously described. The two heat treatments were included to determine the role of microflora in suppression. The treatment with a nitrogen supplement (OC3s-GM-N) was included to control for the effects of nitrogen availability. The two heat treatments were not incubated before sowing. The bioassays were arranged in a randomized design with five replications (pots). For each treatment, three pots not inoculated with $V$. dahliae were included as a negative check in order to evaluate compost effects on plant growth in the absence of disease. These bioassays followed the same protocol as those described previously for all the composted materials, except in this case a lower inoculum concentration $(3.4 \times$ $10^{6}$ conidia/ml) was used, and the $\mathrm{pH}, \mathrm{EC}$, and API-ZYM enzymatic activities, mean, and diversity were determined for each treatment. When the bioassays were completed, the microesclerotia concentration, plant biomass, and microbial density of culturable organisms were also measured.

The concentration of culturable groups of bacteria and fungi in the plant growth media was determined by dilution plating on semiselective media in accordance with Tuitert et al. (1998), with modifications as described by Borrero et al. (2005). At the end of bioassays, samples were collected from the rhizosphere of five pots and combined and mixed for each treatment and bioassay. Five to 10 grams were suspended in $250 \mathrm{ml}$ of $0.1 \%$ tetra-sodium pyrophosphate $\mathrm{Na}_{4} \mathrm{P}_{2} \mathrm{O}_{7} \cdot 10 \mathrm{H}_{2} \mathrm{O}$. The suspension was shaken and a tenfold dilution series was prepared with $0.1 \%$ water agar. After that, aliquots of each suspension and dilution were pipetted onto three plates per culture medium. Four to five dilutions per series were placed on plates with the semiselective culture media. To isolate copiotrophic bacteria, Bacillus spp., fluorescent Pseudomonas spp., oligotrophic and cellulolytic bacteria, and actinomycetes, $100 \mu \mathrm{g}$ of cycloheximide was substituted in semiselective media for $10 \mu \mathrm{g}$ of benomyl per $\mathrm{ml}$ (Energía e Industrias Aragonesas, S.A., Madrid, Spain) and $0.3 \mu l$ of Previcur (Propamocarb, $72.2 \%$, Schering, Alcácer, Spain) per ml. The concentration of Talaromyces spp. in the plant growth media was determined using fungal counts made on a selective medium (Dhingra and Sinclair 1995) composed of potato dextrose agar amended with 1,000 ppm of Tergitol-7 (Fluka Chemie AGB, Buchs, Switzerland) and $50 \mu \mathrm{g}$ of oxytetracycline hydrochloride (Sigma Chemical Company, St Louis, $\mathrm{MO}$ ). Colony forming units (CFU) were counted 4 days after plating and expressed as CFU per ml of plant growth media. Analyses were performed with one sample per plant growth medium treatment and bioassay.

Statistical analysis. Data collected from the bioassays were analyzed using the Statgraphics 6.0 software package. Data had been checked for normal distributions and homoscedasticity using the Barlett and Levenne tests. Any data not passing either test required additional transformation (transformed data $=\operatorname{data}^{1}-b$, with $b$ the slope of the relation between the logarithms of standard deviation and the logarithm of the mean for each treatment $\times$ block $\times$ assay 
combination), which was effective for achieving ANOVA requirements (Hinz and Eagles 1976). Statistical analysis was performed using the general linear model procedure to identify the effects of the factors studied on the different variables measured in the experiments. For the growth media collection in the first series of bioassays, the effect of compost and maturation level on disease severity, BD, $\mathrm{pH}, \mathrm{EC}, \mathrm{GI}, \mathrm{PGI}$, OUR, $\beta$-glucosidase activity, API-ZYM mean activity, API-ZYM Shannon's diversity index, API-ZYM enzymatic activities, and microsclerotia concentration of plant growth media was assessed using factorial ANOVA. For the OC3-GM treatments (second series of bioassays), the effects of the different treatments on disease severity, $\mathrm{pH}$, EC, API-ZYM mean activity, API-ZYM Shannon's diversity index, API-ZYM enzymatic activities, concentration of culturable groups, and microsclerotia concentration of different treatments of OC3-GM were also analyzed with factorial ANOVA. Means were compared using Tukey's whole significant difference test $(P \leq 0.05)$. The overall relationships between severity and the continuous measured variables were analyzed with regression analysis for plant growth media formulated with composts. Peat data were removed for the regression analysis because the objective was the identification of suppressive properties in olive mill composts; API-ZYM enzymatic activity data were also excluded because their variables are semiquantitative and categorical.

\section{Results}

Olive mill compost bioassays. The four bioassays showed that only OC3-GM was suppressive to Verticillium wilt on cotton relative to the unamended peat positive control, independent of the level of maturation (Table 1). The lowest concentration of $V$. dahliae microsclerotia was also observed in OC3-GM by the end of the experiment. When pooled across maturation levels, the short matured composts had significantly lower microsclerotial concentrations than those cured for 1 year (Table 1). Based on AUDPC values, OC2-GM was more favorable for disease development compared with peat, although this difference was not significant (Table 1). Fresh and dry plant shoot weights were negatively correlated with both measured disease-related variables $(P<0.001)$ with similar correlation indexes. Consequently, final severity and AUDPCs reflected disease severity in a similar manner. Plants grown in noninfested control media showed normal growth during cultivation and did not develop symptoms of Verticillium wilt (data not shown).

Physical and chemical properties of the plant growth media. Except for EC, physical and chemical properties of each growth media varied with the level of maturation (Table 2). Plant growth media amended with the short matured composts had higher PGI and lower $\mathrm{BD}, \mathrm{pH}$, and GI. Among the four different plant growth media, the unamended peat control had lower $\mathrm{BD}$ and $\mathrm{pH}$, and higher $\mathrm{EC}$ than compost-amended media. OC3-GM showed the highest $\mathrm{pH}$ value and the lowest EC. Only OC4-GM had significant and similar $\mathrm{pH}$ and higher EC than OC3-GM, when compared with the other plant growth media formulated with composts. For phytotoxicity, only OC4-GM showed significantly lower GI values than peat. For fungitoxicity, OC3-GM and peat showed the lowest PGI values and OC2-GM the highest values.

Biological characteristics of the plant growth media. Plant growth media amended with the longer matured composts showed reduced OUR and $\beta$-glucosidase activity (Table 3 ). However, APIZYM enzymatic activities and their mean and diversity index did not show differences between the two different compost maturation levels, except for $\beta$-galactosidase activity. For this enzyme, plant growth media formulated with more mature composts showed the highest activity (Tables 4 and 5). Peat showed the lowest microbial activity (as evidenced by the lowest OUR, $\beta$-glucosidase, and API-ZYM mean activity) and API-ZYM enzymatic diversity, but it was not significantly different from that of OC2-GM. In comparison, OC1-GM showed the highest OUR, OC4-GM the highest $\beta$-glucosidase activity, and OC3-GM the highest API-ZYM mean activity and diversity (Table 3). The OC3-GM medium also had seven API-ZYM activities (alkaline phosphatase, esterase, esterase lipase, lipase, leucine arylamidase, valine arylamidase, and $\alpha$-glucosidase) that were significantly higher than unamended peat, while OC1-GM, OC2GM, and OC4-GM had five (alkaline phosphatase, esterase, esterase lipase, leucine arylamidase, and $\mathrm{N}$-acetyl- $\beta$-glucosaminidase), three (alkaline phosphatase, leucine arylamidase, and $\beta$-galactosidase), and four (alkaline phosphatase, leucine arylamidase, naphtol-ASBI-phosphohydrolase, and $\mathrm{N}$-acetyl- $\beta$-glucosaminidase) activities, respectively (Table 4 ). Lipase and $\alpha$-glucosidase activities were clearly higher in OC3-GM than in the other plant growth media.

More than $70 \%$ of the variation in AUDPCs across the compost amended media was explained by a multiple linear-regression (MLR) model that included API-ZYM Shannon's diversity index, $\beta$-glucosidase activity, $\mathrm{pH}$, and $\mathrm{EC}$ as predictive variables for Verticillium wilt severity $\left(\mathrm{r}^{2}=0.71, P<0.0001\right)$. These variables were also included in the best model found to estimate microsclerotia concentration at the end of bioassays. This model explained $68 \%$ of the variation in a Napierian logarithm of the microsclerotia concentration $\left(\mathrm{r}^{2}=0.68, P<0.0001\right)$ (Supplementary Figure S1) (both dependent variables are correlated). The AUDPCs calculated explained $49 \%$ of the variation in a Napierian logarithm of the microsclerotia concentration $($ AUDPCs $=0.184+0.129 \times \ln$ microsclerotia concentration; $\left.\mathrm{r}^{2}=0.49, P<0.001\right)$.

Bioassays to elucidate the mechanism of compost suppression. All the treatments amended with OC3s-GM showed Verticillium wilt suppression when compared with the inoculated peat positive control (Table 5). Untreated OC3s-GM and N-supplemented OC3s-GM-N were the most suppressive. The autoclaved treatment demonstrated greater suppressiveness than the treatment heat treated at $60^{\circ} \mathrm{C}$ based on the final disease severity rating data, but had similar AUDPC values. Untreated OC3s-GM had the lowest $V$. dahliae microsclerotia concentration at the end of bioassays (Table 5). Autoclaved and heat treated at $60^{\circ} \mathrm{C}$ media resulted in similar microsclerotia concentration in the rhizosphere when compared with the peat control. Noninfested control plants did not develop symptoms of Verticillium wilt (data not shown).

The different treatments of OC3s-GM (suppressive plant growth medium) changed some chemical and biological properties of the medium. Autoclaving slightly decreased the $\mathrm{pH}$, but did not affect

Table 1. Effect of olive mill compost source and level of maturation on Verticillium wilt disease severity, standardized area under disease progress curve (AUDPC), and microsclerotia (MS) concentration ${ }^{\mathrm{w}}$

\begin{tabular}{lccc}
\hline $\begin{array}{l}\text { Growth } \\
\text { medium }^{\mathbf{x}}\end{array}$ & Severity $^{\mathbf{y}}(\%)$ & $\begin{array}{c}\text { AUDPC } \\
\text { (range 0 to 1) }\end{array}$ & $\begin{array}{c}\text { MS concentration } \\
\text { (MS/g dry weight) }\end{array}$ \\
\hline OC1-GM & $82 \pm 4.5 \mathrm{ab}$ & $0.494 \pm 0.040 \mathrm{~b}$ & $18 \pm 5 \mathrm{a}$ \\
OC2-GM & $96 \pm 2.4 \mathrm{a}$ & $0.729 \pm 0.029 \mathrm{a}$ & $21 \pm 4 \mathrm{a}$ \\
OC3-GM & $43 \pm 5.8 \mathrm{c}$ & $0.203 \pm 0.036 \mathrm{c}$ & $3 \pm 1 \mathrm{~b}$ \\
OC4-GM & $71 \pm 5.2 \mathrm{~b}$ & $0.463 \pm 0.043 \mathrm{~b}$ & $37 \pm 11 \mathrm{a}$ \\
Peat & $84 \pm 4.5 \mathrm{ab}$ & $0.568 \pm 0.041 \mathrm{~b}$ & $54 \pm 11 \mathrm{a}$ \\
Maturation & & & \\
Short & $72 \pm 3.8 \mathrm{a}$ & $0.436 \pm 0.030 \mathrm{a}$ & $24 \pm 6 \mathrm{~b}$ \\
Long & $74 \pm 3.6 \mathrm{a}$ & $0.509 \pm 0.032 \mathrm{a}$ & $30 \pm 5 \mathrm{a}$ \\
\hline
\end{tabular}

${ }^{w}$ Data represent mean \pm standard error. For each column and plant growth medium or level of maturation factor, values followed by different letters are significantly different according to ANOVA and Tukey's Test $(P<$ 0.05). Data for analysis were transformed with $\mathrm{x}^{2}$ for severity, $\mathrm{x}^{0.67}$ for AUDPC, and $x^{0.17}$ for microsclerotia concentration in growth medium. Severity and AUDPC were $n=60$ for growth medium and $n=120$ for level of maturation. Microsclerotia concentration was $n=12$ for growth medium and $n=24$ for level of maturation.

x OC1-GM: growth medium formulated with OC1 compost and peat 1:2 v/v; OC2-GM: growth medium formulated with OC2 compost and peat $1: 2 \mathrm{v} / \mathrm{v}$; OC3-GM: growth medium formulated with OC3 compost and peat $1: 2 \mathrm{v} / \mathrm{v}$; OC4-GM: growth medium formulated with OC4 compost and peat 1:2 v/v. y Disease severity scale: $0=$ asymptomatic plants; $1=$ slightly symptomatic plants ( 1 to $33 \%$ of leaves affected); $2=$ moderately symptomatic plants ( 34 to $66 \%$ of leaves affected); $3=$ severely symptomatic plants (67 to $99 \%$ of leaves affected but plants not dead); and $4=$ dead plants. Each scale score was converted to the midpoint of the corresponding disease severity range.

z Short: compost with a curing phase of 4 months; long: compost with a curing phase of 1 year. 
EC (Table 6). After heating at $60^{\circ} \mathrm{C}$, trypsin activity increased, while acid phosphatase and $\mathrm{N}$-acetyl- $\beta$-glucosaminidase activity decreased. Autoclaving decreased enzymatic diversity, acid phosphatase, and Nacetyl- $\beta$-glucosaminidase activity, while nitrogen supplementation increased acid phosphatase activity (Table 7). It is noteworthy that both heat treatments $\left(60^{\circ} \mathrm{C}\right.$ and autoclaving) eliminated $\mathrm{N}$-acetyl$\beta$-glucosaminidase activity.

Of the cultural microorganisms, the population of Bacillus spp. and the ratio of cellulolytic actinomycetes/cellulolytic bacteria were the highest in growth medium heat treated at $60^{\circ} \mathrm{C}$. Heating at $60^{\circ} \mathrm{C}$ seemed to favor copiotrophic bacteria, but the concentration of these populations did not differ significantly from the untreated OC3s-GM. Nevertheless, copiotrophic bacteria developed higher populations in OC3s-GM-H than in OC3s-GM-A (Table 8).

For OC3s-GM treatments, the best MLR model was found when oligotrophic actinomycetes and Bacillus spp. populations were taken into account as predictive variables. This model explained $86 \%$ of the variation in Verticillium wilt disease severity $\left(\mathrm{r}^{2}=0.86, P<0.001\right)$

Table 2. The physical and chemical properties of the olive mill compost amended growth media prior to use in the bioassays ${ }^{\mathrm{w}}$

\begin{tabular}{|c|c|c|c|c|c|}
\hline \multirow[b]{2}{*}{ Growth medium ${ }^{x}$} & \multicolumn{5}{|c|}{ Properties $^{y}$} \\
\hline & $\mathrm{BD}\left(\mathrm{g} \mathrm{ml}^{-1}\right)$ & pH & $\mathrm{EC}\left(\mathrm{mS} \mathrm{cm}^{-1}\right)$ & GI (\%) & PGI $(\%)$ \\
\hline OC1-GM & $0.24 \pm 0.01 \mathrm{a}$ & $7.81 \pm 0.12 b$ & $0.82 \pm 0.06 \mathrm{bc}$ & $84.9 \pm 8.1 \mathrm{ab}$ & $21.2 \pm 0.8 \mathrm{c}$ \\
\hline OC2-GM & $0.32 \pm 0.05 \mathrm{a}$ & $7.64 \pm 0.07 b$ & $0.88 \pm 0.10 b c$ & $103.4 \pm 8.6 \mathrm{a}$ & $31.5 \pm 0.9 \mathrm{a}$ \\
\hline OC3-GM & $0.32 \pm 0.05 \mathrm{a}$ & $8.09 \pm 0.07 \mathrm{a}$ & $0.73 \pm 0.10 \mathrm{c}$ & $83.8 \pm 7.9 \mathrm{ab}$ & $3.9 \pm 1.0 \mathrm{~d}$ \\
\hline OC4-GM & $0.24 \pm 0.02 \mathrm{a}$ & $7.87 \pm 0.08 \mathrm{ab}$ & $0.98 \pm 0.13 b$ & $61.4 \pm 6.0 \mathrm{~b}$ & $25.7 \pm 1.8 \mathrm{~b}$ \\
\hline Peat & $0.13 \pm 0.01 \mathrm{~b}$ & $5.48 \pm 0.05 \mathrm{c}$ & $2.55 \pm 0.11 \mathrm{a}$ & $102.3 \pm 10.0 \mathrm{a}$ & $1.9 \pm 0.9 \mathrm{~d}$ \\
\hline \multicolumn{6}{|l|}{ Maturation $^{z}$} \\
\hline Short & $0.20 \pm 0.01 \mathrm{~b}$ & $7.27 \pm 0.19 b$ & $1.05 \pm 0.17 \mathrm{a}$ & $76.6 \pm 4.4 \mathrm{~b}$ & $19.6 \pm 1.2 \mathrm{a}$ \\
\hline Long & $0.29 \pm 0.03 \mathrm{a}$ & $7.49 \pm 0.18 \mathrm{a}$ & $1.33 \pm 0.10 \mathrm{a}$ & $97.6 \pm 6.2 \mathrm{a}$ & $14.5 \pm 0.7 b$ \\
\hline
\end{tabular}

${ }^{\mathrm{w}}$ Data represent mean \pm standard error. For each column and plant growth medium or level of maturation factor, values followed by different letters are significantly different according to ANOVA and Tukey's Test $(P<0.05)$. Data for analysis were transformed with $\mathrm{x}^{-1.5}$ for BD, $\mathrm{x}^{-0.2}$ for GI. BD: $n=4$ for growth medium and $n=8$ for level of maturation. $\mathrm{pH}$ and EC: $n=12$ for growth medium and $n=24$ for level of maturation. GI: $n=18$ for growth medium and $n=36$ for level of maturation. PGI: $n=120$ for growth medium and $n=240$ for level of maturation.

x OC1-GM: growth medium formulated with OC1 compost and peat 1:2 v/v; OC2-GM: growth medium formulated with OC2 compost and peat 1:2 v/v; OC3GM: growth medium formulated with OC3 compost and peat 1:2 v/v; OC4-GM: growth medium formulated with OC4 compost and peat 1:2 v/v.

y BD: bulk density; EC: electrical conductivity; GI: germination index; PGI: percentage of Verticillium dahliae mycelial growth inhibition.

z Short: compost with a curing phase of 4 months; long: compost with a curing phase of 1 year.

Table 3. Oxygen uptake rate (OUR), $\beta$-glucosidase activity, API-ZYM mean activity, and Shannon's diversity index of the olive mill compost amended growth media prior to use in the bioassays ${ }^{\mathrm{x}}$

\begin{tabular}{|c|c|c|c|c|}
\hline Growth medium ${ }^{y}$ & OUR (mg O $\left.\mathrm{Og}^{-1} \mathrm{day}^{-1}\right)$ & $\begin{array}{c}\beta \text {-glucosidase activity } \\
\left(\mu \mathrm{g} \rho \text {-nitrofenol } \mathrm{ml}^{-1} \mathbf{h}^{-1}\right)\end{array}$ & API-ZYM mean activity & $\begin{array}{c}\text { API-ZYM Shannon's } \\
\text { diversity index }\end{array}$ \\
\hline OC1-GM & $1,880.1 \pm 177.3 \mathrm{a}$ & $177.1 \pm 12.6 \mathrm{ab}$ & $1.01 \pm 0.08 \mathrm{ab}$ & $2.09 \pm 0.08 \mathrm{ab}$ \\
\hline OC2-GM & $1,189.7 \pm 150.6 \mathrm{bc}$ & $100.1 \pm 6.0 \mathrm{c}$ & $0.69 \pm 0.06 \mathrm{c}$ & $1.86 \pm 0.07 \mathrm{bc}$ \\
\hline OC3-GM & $1,308.3 \pm 103.3 \mathrm{~b}$ & $151.3 \pm 5.4 b$ & $1.11 \pm 0.06 \mathrm{a}$ & $2.22 \pm 0.06 \mathrm{a}$ \\
\hline OC4-GM & $1,439.1 \pm 160.8 \mathrm{~b}$ & $201.6 \pm 19.8 \mathrm{a}$ & $0.90 \pm 0.10 b$ & $2.06 \pm 0.07 \mathrm{ab}$ \\
\hline Peat & $1,037.7 \pm 130.9 \mathrm{c}$ & $62.4 \pm 9.5 \mathrm{c}$ & $0.56 \pm 0.06 \mathrm{c}$ & $1.68 \pm 0.12 \mathrm{c}$ \\
\hline \multicolumn{5}{|l|}{ Maturation $^{\mathrm{z}}$} \\
\hline Short & $1,741.7 \pm 73.9 \mathrm{a}$ & $147.1 \pm 14.4 \mathrm{a}$ & $0.77 \pm 0.05 \mathrm{a}$ & $1.87 \pm 0.06 \mathrm{a}$ \\
\hline Long & $1,000.3 \pm 84.2 b$ & $129.9 \pm 8.5 b$ & $0.94 \pm 0.06 \mathrm{a}$ & $2.09 \pm 0.05 \mathrm{a}$ \\
\hline
\end{tabular}

${ }^{x}$ Data represent mean \pm standard error. For each column and plant growth medium or level of maturation factor, values followed by different letters are significantly different according to ANOVA and Tukey's Test $(P<0.05) . n=12$ for growth medium and $n=24$ for level of maturation.

y OC1-GM: growth medium formulated with OC1 compost and peat 1:2 v/v; OC2-GM: growth medium formulated with OC2 compost and peat 1:2 v/v; OC3-

GM: growth medium formulated with OC3 compost and peat 1:2 v/v; OC4-GM: growth medium formulated with OC4 compost and peat 1:2 v/v.

${ }^{\mathrm{z}}$ Short: compost with a curing phase of 4 months; long: compost with a curing phase of 1 year.

Table 4. The API-ZYM enzymatic activities of olive mill compost amended growth media prior to use in the bioassays ${ }^{x}$

\begin{tabular}{|c|c|c|c|c|c|}
\hline Growth mediumy & $\begin{array}{c}\text { Alkaline } \\
\text { phosphatase }\end{array}$ & Esterase (C4) & Esterase lipase (C8) & Lipase (C14) & $\begin{array}{c}\text { Leucine } \\
\text { arylamidase }\end{array}$ \\
\hline OC1-GM & $2.2 \pm 0.3 \mathrm{~b}$ & $2.8 \pm 0.1 \mathrm{ab}$ & $2.1 \pm 0.1 \mathrm{ab}$ & $0.1 \pm 0.1 \mathrm{~b}$ & $2.7 \pm 0.2 \mathrm{a}$ \\
\hline OC2-GM & $2.6 \pm 0.3 \mathrm{ab}$ & $2.3 \pm 0.2 b c$ & $1.4 \pm 0.1 \mathrm{c}$ & $0.2 \pm 0.1 \mathrm{~b}$ & $1.9 \pm 0.2 \mathrm{~b}$ \\
\hline OC3-GM & $3.3 \pm 0.3 \mathrm{a}$ & $3.2 \pm 0.2 \mathrm{a}$ & $2.6 \pm 0.1 \mathrm{a}$ & $0.8 \pm 0.2 \mathrm{a}$ & $2.8 \pm 0.1 \mathrm{a}$ \\
\hline OC4-GM & $2.3 \pm 0.2 \mathrm{~b}$ & $2.1 \pm 0.1 \mathrm{c}$ & $1.8 \pm 0.1 \mathrm{bc}$ & $0.1 \pm 0.1 b$ & $2.4 \pm 0.2 \mathrm{ab}$ \\
\hline Peat & $0.7 \pm 0.1 \mathrm{c}$ & $2.0 \pm 0.1 \mathrm{c}$ & $1.3 \pm 0.1 \mathrm{c}$ & $0.0 \pm 0.0 \mathrm{~b}$ & $0.8 \pm 0.2 \mathrm{c}$ \\
\hline \multicolumn{6}{|l|}{ Maturation $^{z}$} \\
\hline Short & $2.0 \pm 0.2 \mathrm{a}$ & $2.6 \pm 0.1 \mathrm{a}$ & $1.8 \pm 0.1 \mathrm{a}$ & $0.3 \pm 0.1 \mathrm{a}$ & $2.1 \pm 0.2 \mathrm{a}$ \\
\hline Long & $2.5 \pm 0.2 \mathrm{a}$ & $2.3 \pm 0.1 \mathrm{a}$ & $1.9 \pm 0.1 \mathrm{a}$ & $0.2 \pm 0.1 \mathrm{a}$ & $2.1 \pm 0.1 \mathrm{a}$ \\
\hline
\end{tabular}

\footnotetext{
${ }^{\mathrm{x}}$ Data represent mean \pm standard error. For each column and plant growth medium or level of maturation factor, values followed with different letters are significantly different according to ANOVA and Tukey's Test $(P<0.05)$. Data for analysis were transformed with $\mathrm{x}^{0.59}$ for $\mathrm{N}$-acetyl- $\beta$-glucosaminidase. $n=12$ for growth medium and $n=24$ for level of maturation.

y OC1-GM: growth medium formulated with OC1 compost and peat 1:2 v/v; OC2-GM: growth medium formulated with OC2 compost and peat 1:2 v/v; OC3GM: growth medium formulated with OC3 compost and peat 1:2 v/v; OC4-GM: growth medium formulated with OC4 compost and peat 1:2 v/v.

${ }^{z}$ Short: Compost with a curing phase of 4 months; Long: Compost with a curing phase of 1 year.
} 
These variables were also included in the best model for estimating microsclerotia concentration in the rhizosphere at the end of bioassays. This model explained $74 \%$ of the variation in a Napierian logarithm of the microsclerotia concentration $\left(\mathrm{r}^{2}=0.74, P<0.01\right)$ (Supplementary Figure S2) (both dependent variables are correlated). Final Verticillium wilt severity explained $84.5 \%$ of the variation in a Napierian logarithm of the microsclerotia concentration (severity $=$ $18.17+15.04 \times \ln$ microsclerotia concentration; $r^{2}=0.85, P<$ $0.001)$, meaning that as disease severity increased, so did the concentration of microsclerotia enumerated from the rhizosphere.

\section{Discussion}

There is evidence that certain olive mill composts are suppressive to Verticillium wilt, reduce microsclerotia concentration, or inhibit mycelial growth (Alfano et al. 2011; Arriagada et al. 2012; Castaño and Avilés 2013; Lima et al. 2008; Malandraki et al. 2008; Markakis et al. 2008; Vitullo et al. 2013; Yildiz and Benlioglu 2010). However, our results demonstrate that not all olive mill composts are suppressive to Verticillium wilt when used as an amendment in plant growth media; they can even exacerbate disease compared with peat alone. In these bioassay trials, only the peat formulated with OC 3 compost, regardless of maturation level, was suppressive to Verticillium wilt

Table 5. The effect of $\mathrm{N}$-supplemented and heat treating olive compost amended media (OC3s-GM) on Verticillium wilt disease severity, standardized area under disease progress curve (AUDPC), and microsclerotia (MS) concentration $^{\mathrm{x}}$

\begin{tabular}{lccc}
\hline Treatment $^{\mathbf{y}}$ & Severity $^{\mathbf{z}}(\boldsymbol{\%})$ & $\begin{array}{c}\text { AUDPC } \\
\text { (range 0 to 1) }\end{array}$ & $\begin{array}{c}\text { MS concentration } \\
\text { (MS/g dry weight) }\end{array}$ \\
\hline OC3s-GM & $2.3 \pm 1.5 \mathrm{~d}$ & $0.002 \pm 0.001 \mathrm{c}$ & $0.3 \pm 0.1 \mathrm{c}$ \\
OC3s-GM-N & $11.1 \pm 7.2 \mathrm{~d}$ & $0.066 \pm 0.055 \mathrm{c}$ & $1.1 \pm 0.2 \mathrm{~b}$ \\
OC3s-GM-A & $44.4 \pm 10.1 \mathrm{c}$ & $0.183 \pm 0.068 \mathrm{~b}$ & $5.6 \pm 0.5 \mathrm{a}$ \\
OC3s-GM-H & $77.7 \pm 9.8 \mathrm{~b}$ & $0.292 \pm 0.076 \mathrm{~b}$ & $69.5 \pm 52 \mathrm{a}$ \\
Peat & $97.7 \pm 1.5 \mathrm{a}$ & $0.553 \pm 0.050 \mathrm{a}$ & $52.8 \pm 7.3 \mathrm{a}$ \\
\hline
\end{tabular}

${ }^{\mathrm{x}}$ Data represent mean \pm standard error. For each column, values followed by different letters are significantly different according to ANOVA and Tukey's Test $(P<0.05)$. Data for analysis were transformed with $\mathrm{x}^{0.6}$ for severity, $\mathrm{x}^{0.28}$ for AUDPC, and $\mathrm{x}^{-0.3}$ for microsclerotia concentration. $n=15$ for severity and AUDPC and $n=3$ for microsclerotia concentration.

y OC3s-GM: growth medium formulated with short maturation OC3 compost and peat $1: 2 \mathrm{v} / \mathrm{v}$; OC3s-GM-N: OC3s-GM fertilized with $0.52 \mathrm{~g} /$ liter of ammonia nitrate; OC3s-GM-A: OC3s-GM autoclaved (two successive times within a $24 \mathrm{~h}$ interval for $1 \mathrm{~h}$ at $120^{\circ} \mathrm{C}, 1.2 \mathrm{~atm}$ ); OC3s-GM-H: OC3s-GM heated (at $60^{\circ} \mathrm{C}$ for 6 days).

${ }^{\mathrm{z}}$ Disease severity scale: $0=$ asymptomatic plants; $1=$ slightly symptomatic plants ( 1 to $33 \%$ of leaves affected); $2=$ moderately symptomatic plants ( 34 to $66 \%$ of leaves affected); $3=$ severely symptomatic plants (67 to $99 \%$ of leaves affected but plants not dead); and $4=$ dead plants. Each scale score was converted to the midpoint of the corresponding disease severity range. when compared with peat, an effect that was related to a lower concentration of microsclerotia at the end of bioassays. On the other hand, compost maturation did not affect disease suppressiveness, despite the fact that short matured composts were shown to have a lower microsclerotia concentration at the end of bioassays than long matured composts. The relationship between the compost curing duration and disease suppression was not always clear. There is evidence for decreased suppressiveness in compost with increased age for Phytophthora spp. (Danon et al. 2007), Pythium spp. (Darby et al. 2006; Stone et al. 2001), and Sclerotium rolfsii (Danon et al. 2007). However, evidence also exists for an increased suppressive effect in more matured compost, in the case of Fusarium wilt on melon (Saadi et al. 2010), and Rhizoctonia solani on cucumber (Trillas et al. 2006; Tuitert et al. 1998). Thus, the effects of maturation on compost suppressiveness seem to depend on the nature of the composted materials and the pathosystem (Avilés et al. 2011; Hoitink and Boehm 1999).

For the four olive mill composts studied in these bioassays, the explicative factors for Verticillium wilt disease severity and the final rhizosphere microsclerotia concentration were determined to be API-ZYM Shannon's diversity index, $\beta$-glucosidase activity, $\mathrm{pH}$ (negatively related), and EC (positively related) based on the best MRL models. In the present experimental design, disease severity and microsclerotia concentration were considered dependent variables, because $V$. dahliae inoculation was carried out in plant growth media free from this pathogen. Papasotiriou et al. (2013) also proposed that the suppressive effect of olive mill compost on $V$. dahliae on eggplant was due to abiotic and biotic factors. In order to explain the possible biological meaning of these predictive factors and the complex mechanism involved, it is important to discuss the biological effect of each factor. Castaño and Avilés (2013), also working with different composts formulated as plant growth media, found negative correlations between olive and cotton Verticillium wilt disease severity, $\beta$-glucosidase activity, and $\mathrm{pH}$. For green manure amendments, Ochiai et al. (2008) included microbial activity, $\mathrm{pH}$, and inoculum density in their best MLR model for Verticillium wilt disease in potato. Nevertheless, in this regression model, $\mathrm{pH}$ had a positive relation to disease severity. The difference in the direction of these relationships with the $\mathrm{pH}$ could be due to the range of $\mathrm{pH}$ studied. In the present work, the $\mathrm{pH}$ of plant growth medium amended with olive mill composts ranged from 7.64 to 8.09 , while in Ochiai et al. (2008) the $\mathrm{pH}$ range was from 5.2 to 7.5. Therefore, in acid or neutral media, $\mathrm{pH}$ increase seems to favor Verticillium wilt while in alkaline media, such as plant growth media with olive mill composts, decreasing $\mathrm{pH}$ seemed to favor this disease and is consistent with other research where Verticillium wilt of tomato and cotton increased in acidic soils limed to increase pH (Jones et al. 1971; Shao and Foy 1982). Furthermore, certain actinomycetes, which are $V$. dahliae antagonists, are more antagonistic in alkaline $\mathrm{pHs}$ (Abd-Allah 2001; Shahidi Bonjar and Aghighi 2005).

Table 4. (continued from preceding page)

\begin{tabular}{|c|c|c|c|c|c|c|}
\hline Valine arylamidase & $\begin{array}{c}\text { Acid } \\
\text { phosphatase }\end{array}$ & $\begin{array}{c}\text { Naphtol-AS-BI- } \\
\text { phosphohydrolase }\end{array}$ & $\beta$-galactosidase & $\alpha$-glucosidase & $\beta$-glucosidase & $\mathrm{N}$-acetyl- $\beta$-glucosaminidase \\
\hline $0.4 \pm 0.1 \mathrm{ab}$ & $4.0 \pm 0.3 \mathrm{a}$ & $1.2 \pm 0.1 \mathrm{ab}$ & $0.3 \pm 0.1 \mathrm{ab}$ & $0.2 \pm 0.1 \mathrm{~b}$ & $1.1 \pm 0.1 \mathrm{a}$ & $1.3 \pm 0.3 \mathrm{a}$ \\
\hline $0.3 \pm 0.1 b$ & $2.8 \pm 0.3 \mathrm{~b}$ & $0.8 \pm 0.1 \mathrm{~b}$ & $0.1 \pm 0.1 \mathrm{~b}$ & $0.1 \pm 0.1 \mathrm{~b}$ & $0.1 \pm 0.1 \mathrm{~b}$ & $0.2 \pm 0.1 \mathrm{~b}$ \\
\hline $0.8 \pm 0.1 \mathrm{a}$ & $3.1 \pm 0.2 b$ & $0.8 \pm 0.1 \mathrm{~b}$ & $0.3 \pm 0.1 \mathrm{ab}$ & $0.6 \pm 0.1 \mathrm{a}$ & $0.9 \pm 0.1 \mathrm{a}$ & $0.9 \pm 0.2 \mathrm{ab}$ \\
\hline $0.3 \pm 0.1 \mathrm{~b}$ & $2.9 \pm 0.4 \mathrm{~b}$ & $1.7 \pm 0.2 \mathrm{a}$ & $0.4 \pm 0.1 \mathrm{ab}$ & $0.0 \pm 0.0 \mathrm{~b}$ & $1.1 \pm 0.5 \mathrm{a}$ & $1.3 \pm 0.3 \mathrm{a}$ \\
\hline $0.1 \pm 0.1 \mathrm{~b}$ & $3.5 \pm 0.3 \mathrm{ab}$ & $0.8 \pm 0.2 b$ & $0.6 \pm 0.1 \mathrm{a}$ & $0.0 \pm 0.0 \mathrm{~b}$ & $0.4 \pm 0.1 \mathrm{ab}$ & $0.2 \pm 0.1 \mathrm{~b}$ \\
\hline $0.3 \pm 0.1 \mathrm{a}$ & $2.9 \pm 0.2 \mathrm{a}$ & $1.0 \pm 0.1 \mathrm{a}$ & $0.1 \pm 0.1 \mathrm{~b}$ & $0.1 \pm 0.1 \mathrm{a}$ & $0.4 \pm 0.1 \mathrm{a}$ & $0.7 \pm 0.2 \mathrm{a}$ \\
\hline $0.5 \pm 0.1 \mathrm{a}$ & $3.6 \pm 0.2 \mathrm{a}$ & $1.1 \pm 0.1 \mathrm{a}$ & $0.6 \pm 0.1 \mathrm{a}$ & $0.2 \pm 0.1 \mathrm{a}$ & $1.0 \pm 0.2 \mathrm{a}$ & $0.8 \pm 0.2 \mathrm{a}$ \\
\hline
\end{tabular}


As for EC, some authors have observed that irrigating with saline water boosted $V$. dahliae infections in potato, pistachio, and cotton (Besri 1981; Kaufman et al. 1990; Mohammadi et al. 2007). Other works have demonstrated that salinity increases root and shoot colonization by $V$. dahliae and consequently increases the disease severity (Levin et al. 2007; Pascual et al. 2009; Saadatmand et al. 2008). These authors also suggested salinity as a possible cause for the enhancement of Verticillium wilt in pepper, further confirming the important role of EC in increasing Verticillium wilt development similar to the MLR models proposed here.

Compost amendments have been shown to affect microbial community structure and composition and can enhance microbial diversity (Bonilla et al. 2012; D’Hose et al. 2014; Saison et al. 2006). Disease suppressiveness is often related to overall increases microbial

Table 6. $\mathrm{pH}$ and electrical conductivity (EC) in treatments of identified suppressive olive mill compost $(\mathrm{OC} 3 \mathrm{~s}-\mathrm{GM})$ prior to use in bioassays ${ }^{\mathrm{y}}$

\begin{tabular}{lcc}
\hline Treatment $^{\mathbf{z}}$ & $\mathbf{p H}$ & $\mathbf{E C}\left(\boldsymbol{\mu S} \mathbf{~ c m}^{-\mathbf{1}}\right)$ \\
\hline OC3s-GM & $7.85 \pm 0.021 \mathrm{a}$ & $603 \pm 42 \mathrm{~b}$ \\
OC3s-GM-N & $7.72 \pm 0.10 \mathrm{a}$ & $439 \pm 65 \mathrm{~b}$ \\
OC3s-GM-A & $7.38 \pm 0.05 \mathrm{~b}$ & $544 \pm 10 \mathrm{~b}$ \\
OC3s-GM-H & $7.75 \pm 0.75 \mathrm{a}$ & $585 \pm 69 \mathrm{~b}$ \\
Peat & $5.14 \pm 0.01 \mathrm{c}$ & $2,776 \pm 199 \mathrm{a}$ \\
\hline
\end{tabular}

y Data represent mean \pm standard error. For each column, values followed by different letters are significantly different according to ANOVA and Tukey's Test $(P<0.05)$. Data for analysis were transformed with $\log (\mathrm{x})$ for EC. $n=3$ for $\mathrm{pH}$ and EC.

${ }^{\mathrm{z}}$ OC3s-GM: growth medium formulated with short maturation OC 3 compost and peat $1: 2 \mathrm{v} / \mathrm{v}$; OC3s-GM-N: OC3s-GM fertilized with $0.52 \mathrm{~g} /$ liter of ammonium nitrate; OC3s-GM-A: OC3s-GM autoclaved (two successive times within a $24 \mathrm{~h}$ interval for $1 \mathrm{~h}$ at $120^{\circ} \mathrm{C}, 1.2 \mathrm{~atm}$ ); OC3s-GM-H: OC3s-GM heated (at $60^{\circ} \mathrm{C}$ for 6 days). biomass and activity in plant growth media or soils, which create a competitive environment that is deleterious to the pathogen (Bonanomi et al. 2010; Bonilla et al. 2012; Hadar and Papadopoulou 2012; Larkin 2015). Larkin et al. (2011), working with green manures, found high diversity (Shannon's index) and the highest microbial activity in the treatment with the lowest severity in Verticillium wilt on potato. In the same sense, other authors working with organic soil amendments have found negative correlations between microbial activity and the disease severity of Verticillium wilt on potato (Conn and Lazarovits 1999; Davis et al. 1994, 1996). Conversely, with composts formulated as plant growth media, Termorshuizen et al. (2006) found a positive correlation between respiration and disease severity of Verticillium wilt on eggplant, but were unable to clearly explain this relationship.

Regarding other properties evaluated in this study, the low fungitoxicity observed in the suppressive medium OC3-GM compared with the other media did not seem to be an important factor for suppressiveness, given that the medium with the highest fungitoxicity, OC2-GM, also showed the highest AUDPC value. On the other hand, the high level of lysogenic enzymatic activity found in OC3-GM could be associated with fungal cell wall degradation. Cell walldegrading enzymes are involved in the antagonistic activity of biocontrol agents against phytopathogenic fungi (Elad 1985; Gajera et al. 2012; Madi et al. 1997).

To elucidate the main mechanisms explaining the suppressive effects of OC3s-GM, it was altered with treatments designed to disrupt the microbial community and assess the role of nitrogen on disease suppression. The predictive factors for suppressiveness obtained from the initial bioassays conducted using the growth media amended with four olive composts do not necessary correspond to the explicative suppressive properties observed from the bioassays conducted with OC3s-GM. The microbial communities of the different OC3sGM treatments were triggered by a response to disturbances created through the heat treatment or nitrogen application. The same organic

Table 7. API-ZYM enzymatic activities, mean activity, and Shannon's diversity index in treatments of identified suppressive olive mill compost (OC3s-GM) prior to use in bioassays ${ }^{\mathrm{y}}$

\begin{tabular}{lccccccc}
\hline Treatment & $\begin{array}{c}\text { Shannon's } \\
\text { diversity index }\end{array}$ & $\begin{array}{c}\text { API-ZYM } \\
\text { mean activity }\end{array}$ & $\begin{array}{c}\text { Alkaline } \\
\text { phosphatase }\end{array}$ & $\begin{array}{c}\text { Esterase } \\
\text { lipase }(\mathbf{C 8})\end{array}$ & Trypsin & $\begin{array}{c}\text { Acid } \\
\text { phosphatase }\end{array}$ & N-acetyl- $\boldsymbol{\beta}$-glucosaminidase \\
\hline OC3s-GM & $2.23 \pm 0.06 \mathrm{ab}$ & $0.95 \pm 0.05 \mathrm{ab}$ & $2.0 \pm 0.0 \mathrm{ab}$ & $2.0 \pm 0.0 \mathrm{ab}$ & $0.0 \pm 0.0 \mathrm{~b}$ & $3.0 \pm 0.0 \mathrm{~b}$ & $1.0 \pm 0.0 \mathrm{a}$ \\
OC3s-GM-N & $2.06 \pm 0.02 \mathrm{bc}$ & $0.98 \pm 0.03 \mathrm{ab}$ & $2.3 \pm 0.3 \mathrm{ab}$ & $2.0 \pm 0.0 \mathrm{ab}$ & $0.0 \pm 0.0 \mathrm{~b}$ & $4.3 \pm 0.3 \mathrm{a}$ & $1.0 \pm 0.0 \mathrm{a}$ \\
OC3s-GM-A & $1.56 \pm 0.22 \mathrm{c}$ & $0.47 \pm 0.21 \mathrm{~b}$ & $1.6 \pm 0.6 \mathrm{~b}$ & $1.3 \pm 0.3 \mathrm{~b}$ & $0.0 \pm 0.0 \mathrm{~b}$ & $1.0 \pm 0.0 \mathrm{c}$ & $0.0 \pm 0.0 \mathrm{~b}$ \\
OC3s-GM-H & $2.42 \pm 0.02 \mathrm{a}$ & $1.05 \pm 0.06 \mathrm{a}$ & $3.6 \pm 0.3 \mathrm{a}$ & $2.6 \pm 0.3 \mathrm{a}$ & $1.3 \pm 0.3 \mathrm{a}$ & $1.0 \pm 0.0 \mathrm{c}$ & $0.0 \pm 0.0 \mathrm{~b}$ \\
Peat & $1.98 \pm 0.06 \mathrm{bc}$ & $0.84 \pm 0.05 \mathrm{ab}$ & $1.0 \pm 0.0 \mathrm{~b}$ & $2.0 \pm 0.0 \mathrm{ab}$ & $0.0 \pm 0.0 \mathrm{~b}$ & $5.0 \pm 0.0 \mathrm{a}$ & $0.3 \pm 0.1 \mathrm{ab}$ \\
\hline
\end{tabular}

${ }^{y}$ Data represent mean \pm standard error. For each column, values followed by different letters are significantly different according to ANOVA and Tukey's Test $(P<$ 0.05). Data for analysis were transformed with $\mathrm{x}^{2}$ for mean activity and $\mathrm{x}^{4}$ for Shannon's diversity index. For all parameters, $n=3$.

${ }^{\mathrm{z}}$ OC3s-GM: growth medium formulated with short maturation OC 3 compost and peat 1:2 v/v; OC3s-GM-N: OC3s-GM fertilized with $0.52 \mathrm{~g} /$ liter of ammonium nitrate; OC3s-GM-A: OC3s-GM autoclaved (two successive times within a $24 \mathrm{~h}$ interval for $1 \mathrm{~h}$ at $120^{\circ} \mathrm{C}, 1.2 \mathrm{~atm}$ ); $\mathrm{OC} 3 \mathrm{~s}-\mathrm{GM}-\mathrm{H}$ : $\mathrm{OC} 3 \mathrm{~s}-\mathrm{GM}$ heated (to $60^{\circ} \mathrm{C}$ for 6 days).

Table 8. Microbial ecological-nutrient groups in treatments of identified suppressive olive mill compost (OC3s-GM) at the end of bioassays ${ }^{\mathrm{v}}$

\begin{tabular}{lccccc}
\hline & \multicolumn{5}{c}{$\left(\mathbf{C F U} / \mathbf{m l}\right.$ growth medium $\left.\times \mathbf{1 0}^{\mathbf{5}}\right)$} \\
\cline { 2 - 6 } Treatment $^{\mathbf{w}}$ & Oligotrophic bacteria & Oligotrophic actinomycetes & Cellulolytic bacteria & Cellulolytic actinomycetes & Copiotrophic bacteria \\
\hline OC3s-GM & $527.84 \mathrm{ab}$ & $51.46 \mathrm{a}$ & $233.58 \mathrm{a}$ & $31.22 \mathrm{a}$ & $542.23 \mathrm{ab}$ \\
OC3s-GM-N & $423.00 \mathrm{ab}$ & $36.37 \mathrm{a}$ & $366.88 \mathrm{a}$ & $18.57 \mathrm{a}$ & $277.85 \mathrm{~b}$ \\
OC3s-GM-A & $739.05 \mathrm{a}$ & $5.02 \mathrm{a}$ & $472.72 \mathrm{a}$ & $16.91 \mathrm{a}$ & $347.81 \mathrm{~b}$ \\
OC3s-GM-H & $730.11 \mathrm{a}$ & $71.66 \mathrm{a}$ & $78.48 \mathrm{a}$ & $75.53 \mathrm{a}$ & $1,154.30 \mathrm{a}$ \\
Peat & $197.09 \mathrm{~b}$ & $19.96 \mathrm{a}$ & $164.09 \mathrm{a}$ & $6.79 \mathrm{a}$ & $129.45 \mathrm{~b}$ \\
& & & & & $($ continued on next page)
\end{tabular}

\footnotetext{
${ }^{v}$ Within each column, values followed by different letters are significantly different based on Tukey's test at $P<0.05$. Analysis of variance was performed with transformed data in $\mathrm{x}^{0.35}$ for oligotrophic bacteria, $(\mathrm{x})^{0.4}$ for copiotrophic bacteria, and $\log (\mathrm{x})$ for oligotrophic actinomycetes, cellulolytic bacteria, copiotrophic actinomycetes, and fungi, $n=3$.

w OC3s-GM: growth medium formulated with short maturation OC3 compost and peat 1:2 v/v; OC3s-GM-N: OC3s-GM fertilized with $0.52 \mathrm{~g} /$ liter of ammonium nitrate; OC3s-GM-A: OC3s-GM autoclaved (two successive times within a $24 \mathrm{~h}$ interval for $1 \mathrm{~h}$ at $120^{\circ} \mathrm{C}, 1.2 \mathrm{~atm}$ ); OC3s-GM-H: OC3s-GM heated (to $60^{\circ} \mathrm{C}$ for 6 days).

$x$ Oligotrophic actinomycetes/oligotrophic bacteria.

y Cellulolytic actinomycetes/cellulolytic bacteria.

${ }^{z}$ Oligotrophic bacteria/copiotrophic bacteria.
} 
matter composition can show different functional abilities depending on the microbial community it harbors (van Bruggen and Semenov 2000). The varying Verticillium wilt severity between the heat treatments could be due to their different effects on the microbial community, without discarding possible minor changes in the organic matrix.

Nitrogen supplementation did not affect suppressiveness; rather, it contributed slightly to increased microsclerotia concentration. An increment in nitrogen availability can help microsclerotia to overcome fungistasis (Green and Papavizas 1968). Therefore, this loss of fungistasis could allow microsclerotia to thrive in the presence of the host plant, which would explain the increase in concentration observed. In any case, a possible low availability of nitrogen in untreated OC3s-GM as a cause of suppressiveness is ruled out, given that $\mathrm{N}$-supplemented OC3s-GM-N maintains the same level of suppressiveness.

For the different treatments of suppressive OC3s-GM, both heat treatments $\left(60^{\circ} \mathrm{C}\right.$ heat treated and autoclaved) caused an important drop in suppressiveness, but heating at $60^{\circ} \mathrm{C}$ most significantly increased disease severity. Nevertheless, the heat treatments were still suppressive in comparison with unamended peat, despite showing a similar microsclerotia concentration at the end of bioassays. In contrast, the untreated OC3s-GM medium showed very low microsclerotia concentration. Therefore, the suppressiveness and the absence of a reduction in microsclerotia in heat treatments compared with peat could indicate that untreated OC3s-GM suppressiveness is due to the presence of both general and specific suppressiveness. Alfano et al. (2011) also suggested general and specific suppressiveness in this kind of compost against Pythium ultimum and Fusarium oxysporum f.sp. lycopersici in tomato. The differential suppressive effect of $60^{\circ} \mathrm{C}$ heat treatment compared with untreated OC3s-GM seems to indicate that mesophilic thermo-tolerant taxa are not involved in specific suppression in this compost. Therefore, the relatively higher Bacillus spp. concentration observed in OC $3 \mathrm{~s}-\mathrm{GM}-\mathrm{H}$ compared with the other treatments proves that these microorganisms, which are usually described as biocontrol agents, do not play a major role in the specific suppressiveness of this plant growth medium. On the other hand, increased cellulolytic actinomycetes compared with cellulolytic bacteria in OC3s-GM-H seem to be related to decreased suppressiveness, which contradicts observations by Tuitert et al. (1998) for $R$. solani in household waste composts and Borrero et al. (2004) for tomato Fusarium wilt in other agro-industrial waste composts. The higher mean level of API-ZYM activity and diversity, alkaline phosphatase, esterase lipase, and trypsin activities in OC3sGM-H than in OC3s-GM-A must be due to these thermo-tolerant taxa.

After both heat treatments, $\mathrm{N}$-acetyl- $\beta$-glucosaminidase activity was not detected and acid phosphatase activity decreased. Therefore, microorganisms contributing to these activities (especially $\mathrm{N}$-acetyl$\beta$-glucosaminidase) could be involved in the specific suppressiveness observed in this plant growth medium. $\mathrm{N}$-acetyl- $\beta$-glucosaminidase activity is used as an index of chitinolytic activity in environmental samples (O'Brien and Colwell 1987). Chitinolytic enzymes have been considered important in the biocontrol of soilborne pathogens because of their ability to degrade fungal cell walls (Haran et al. 1996; Harman et al. 1993; Inbar and Chet 1995; Nguyen et al. 2008). Several chitinolytic enzymes have been identified in different kinds of microorganisms, including various species of Streptomyces (Kinkel et al. 2012; Xue et al. 2013). In the same way, acid phosphatase has been suggested to play a role in cell wall hydrolysis of phytopathogens (Monteiro et al. 2010) and microbial phosphatase activity in the rhizosphere has been demonstrated to enhance plant nutrition and consequently plant development and health (Recena et al. 2015). The best LMR model found to explain disease severity and microsclerotia concentration in the different treatments of the suppressive compost OC3s-GM showed the importance of populations of oligotrophic actinomycetes and Bacillus spp. In this compost, oligotrophic actinomycetes seem to favor disease suppression, while Bacillus spp. populations did not. Many actinomycete taxa, such as Streptomyces, are associated with plant disease suppression in many soils (Kinkel et al. 2012; Xue et al. 2013) and are soil saprophytes with a crucial role in nutrient cycling (Kennedy 1999). On the other hand, oligotrophic populations are related to soils with high microbial diversity and suppressiveness (van Bruggen and Semenov 2000). In the same way, in other plant growth media formulated with composts, higher oligotrophic actinomycetes populations were found that were suppressive to $R$. solani on cucumber (Tuitert et al. 1998) and Fusarium wilt on tomato (Borrero et al. 2004). In plant growth media amended with olive mill compost that was suppressive to Fusarium wilt on tomato and $P$. ultimum, high actinomycete and microbial quitinolytic aerobic populations were found (Alfano et al. 2011).

These results suggest that olive mill composts demonstrated to be suppressive to Verticillium wilt, such as OC3, and used to amend nursery plant growth media, can protect plantlets from this disease, at least during the transplant phase. The lack of disease symptoms that developed in non- $V$. dahliae inoculated control treatments containing olive mill composts indicated that these composts are also generally free of this pathogen. We can conclude that olive mill composts amended plant growth media are not always suppressive against Verticillium wilt. However, for these four compost sources, maturation level did not affect disease development. API-ZYM Shannon's diversity index, $\beta$-glucosidase activity, $\mathrm{pH}$, and EC in olive mill compost plant growth media were the factors that best described Verticillium wilt disease severity and rhizosphere microsclerotia concentration. In the olive mill compost that was characterized as suppressive (OC3s-GM), general and specific suppressiveness were both involved. In this compost, $\mathrm{N}$-acetyl- $\beta$-glucosaminidase activity and the oligotrophic actinomycete populations seemed to be involved in suppressiveness.

Table 8. (continued from preceding page)

\begin{tabular}{|c|c|c|c|c|c|c|c|}
\hline \multicolumn{8}{|c|}{$\left(\mathrm{CFU} / \mathrm{ml}\right.$ growth medium $\left.\times 10^{5}\right)$} \\
\hline Copiotrophic actinomycetes & Bacillus spp. & Talaromyces spp. & Pseudomonas spp. & Fungi & OA/OB ${ }^{x}$ & $\mathrm{CA} / \mathrm{CB}^{\mathrm{y}}$ & $\mathrm{OB} / \mathrm{CoB}^{\mathrm{z}}$ \\
\hline $16.40 \mathrm{a}$ & $16.43 \mathrm{~b}$ & $0.00 \mathrm{a}$ & $0.01 \mathrm{a}$ & $4.11 \mathrm{a}$ & $0.12 \mathrm{a}$ & $0.11 \mathrm{~b}$ & $1.17 \mathrm{a}$ \\
\hline $8.29 \mathrm{a}$ & $6.00 \mathrm{~b}$ & $0.00 \mathrm{a}$ & $0.01 \mathrm{a}$ & $1.30 \mathrm{a}$ & $0.10 \mathrm{a}$ & $0.11 \mathrm{~b}$ & $2.36 \mathrm{a}$ \\
\hline $0.43 \mathrm{a}$ & $24.64 \mathrm{~b}$ & $0.00 \mathrm{a}$ & $0.06 \mathrm{a}$ & $3.30 \mathrm{a}$ & $0.01 \mathrm{a}$ & $0.03 \mathrm{~b}$ & $8.82 \mathrm{a}$ \\
\hline $42.09 \mathrm{a}$ & $72.75 \mathrm{a}$ & $0.00 \mathrm{a}$ & $0.07 \mathrm{a}$ & $2.76 \mathrm{a}$ & $0.10 \mathrm{a}$ & $0.83 \mathrm{a}$ & $0.70 \mathrm{a}$ \\
\hline $2.21 \mathrm{a}$ & $1.48 \mathrm{~b}$ & $0.00 \mathrm{a}$ & $0.00 \mathrm{a}$ & $1.31 \mathrm{a}$ & $0.10 \mathrm{a}$ & $0.06 \mathrm{~b}$ & $1.55 \mathrm{a}$ \\
\hline
\end{tabular}




\section{Acknowledgements}

This research was supported by grants from Spain's Ministerio de Ciencia e Innovación (AGL2010-21982-C02-01). We would like to thank A. Gata, S. Castillo, S. Pérez, and R. Castaño for their excellent technical assistance; D. Delgado and F. Forcella for kindly revising the manuscript, and J. M. Álvarez for finding and supplying the composts.

\section{Literature Cited}

Abd-Allah, E. F. 2001. Streptomyces plicatus as a model biocontrol agent. Folia Microbiol. (Praha) 46:309-314.

AENOR. 2002. Norma Española UNE-EN 13654-2. Soil improvers and growing media - Determination of nitrogen - Part 2: Dumas method. Spanish Association for Standardization and Certification (AENOR), Madrid, Spain.

Alfano, G., Lustrato, G., Lima, G., Vitullo, D., Delfine, S., Tognetti, R., and Ranalli, G. 2009. Physico-chemical, microbiological, agronomical and phytopathological aspects in the recycling of olive waste composted residues. Dyn. Soil Dyn. Plant 3: 64-72.

Alfano, G., Lustrato, G., Lima, G., Vitullo, D., and Ranalli, G. 2011. Characterization of composted olive mill wastes to predict potential plant disease suppressiveness. Biol. Control 58:199-207.

Arriagada, C., García-Sánchez, M., Díaz, R., Sampedro, I., Aranda, E., GarcíaRomera, I., and Ocampo, J. A. 2012. Suppressive effect of olive residue and saprophytic fungi on the growth of Verticillium dahliae and its effect on the dry weight of tomato (Solanum lycopersicum L.). J. Soil Sci. Plant Nutr. 12: 303-313.

Avilés, M., Borrero, C., and Trillas, M. 2011. Review on compost as an inducer of disease suppression in plants grown in soilless culture. Dyn. Soil Dyn. Plant 5 (Special Issue 2):1-11.

Bandick, A. K., and Dick, R. P. 1999. Field management effects on soil enzyme activities. Soil Biol. Biochem. 31:1471-1479.

Bejarano-Alcázar, J., Melero-Vara, J. M., Blanco-López, M. A., and Jiménez-Díaz, R. M. 1995. Infuence of inoculum density of defoliating and nondefoliating pathotypes of Verticillium dahliae on epidemics of Verticillium wilt of cotton in Southern Spain. Phytopathology 85:1474-1481.

Besri, M. 1981. Qualité des sols et des eaux d'irrigation et manifestation des tracheomycoses de la tomate au Maroc. Phytopathol. Mediterr. 20:107-111.

Bonanomi, G., Antignani, V., Capodilupo, M., and Scala, F. 2010. Identifying the characteristics of organic soil amendments that suppress soilborne plant diseases. Soil Biol. Biochem. 42:136-144.

Bonilla, N., Gutiérrez-Barranquero, J. A., De Vicente, A., and Cazorla, F. M. 2012. Enhancing soil quality and plant health through suppressive organic amendments. Diversity (Basel) 4:475-491.

Borrero, C., Infantes, M. J., González, E., and Avilés, M. 2005. Relation between suppressiveness to tomato Fusarium wilt and microbial populations in different growth media. Acta Hortic. 697:425-430.

Borrero, C., Trillas, I., and Avilés, M. 2009. Carnation Fusarium wilt suppression in four composts. Eur. J. Plant Pathol. 123:425-433.

Borrero, C., Trillas, M. I., Ordovás, J., Tello, J. C., and Avilés, M. 2004. Predictive factors for the suppression of Fusarium wilt of tomato in plant growth media. Phytopathology 94:1094-1101.

Caballero, R., Pajuelo, P., Ordovás, J., Carmona, E., and Delgado, A. 2009. Evaluation and correction of nutrient availability to Gerbera jamesonii H. Bolus in various compost-based growing media. Sci. Hortic. (Amsterdam) 122:244-250.

Campbell, C., and Madden, L. 1990. Introduction to plant disease epidemiology. Wiley, New York.

Castaño, R., and Avilés, M. 2013. Factors that affect the capacity of growing media to suppress Verticillium wilt. Acta Hortic. 1013:465-471.

Cayuela, M. L., Millner, P. D., Meyer, S. L. F., and Roig, A. 2008. Potential of olive mill waste and compost as biobased pesticides against weeds, fungi, and nematodes. Sci. Total Environ. 399:11-18.

Chowdhury, A. K. M. M. B., Akratos, C. S., Vayenas, D. V., and Pavlou, S. 2013. Olive mill waste composting: A review. Int. Biodeterior. Biodegradation $85: 108-119$.

Conn, K. L., and Lazarovits, G. 1999. Impact of animal manures on verticillium wilt, potato scab, and soil microbial populations. Can. J. Plant Pathol. 21: 81-92.

D’Hose, T., Cougnon, M., De Vliegher, A., Vandecasteele, B., Viaene, N., Cornelis, W., Van Bockstaele, E., and Reheul, D. 2014. The positive relationship between soil quality and crop production: A case study on the effect of farm compost application. Appl. Soil Ecol. 75:189-198.

Danon, M., Zmora-Nahum, S., Chen, Y., and Hadar, Y. 2007. Prolonged compost curing reduces suppression of Sclerotium rolfsii. Soil Biol. Biochem. 39: 1936-1946.

Darby, H. M., Stone, A. G., and Dick, R. P. 2006. Compost and manure mediated impacts on soilborne pathogens and soil quality. Soil Sci. Soc. Am. J. 70: 347-358.

Davis, J., Huisman, O., Westermann, D., Sorensen, L., Schneider, A., and Stark, J. 1994. The influence of cover crops on the supression of Verticillium wilt of potato. Pages 332-341 in: Advances in Potato Pest Biology and Management.
G. Zehnder, M.Powelson, R. Jannson and Ramay K. eds. APS Press, St. Paul, MN.

Davis, J. R., Huisman, O. C., Westermann, D. T., Hafez, S. L., Everson, D. O., Sorensen, L. H., and Schneider, A. T. 1996. Effects of green manures on verticillium wilt of potato. Phytopathology 86:444-453.

De Boodt, M., Verdonk, O., and Cappaert, I. 1974. Method for measuring the water release curve of organic substrates. Acta Hortic. 37:2054-2063.

Dhingra, O. D., and Sinclair, J. B. 1995. Basic Plant Pathology Methods, 2nd Ed. CRC Press, Boca Ratón, FL.

Elad, Y. 1985. Mechanisms of interaction between rhizosphere microorganisms and soilborne plant pathogens. Pages 49-59 in: Microbial Communities in Soil. V. Jensen, A. Kjoiler, and Sorensen L. H., eds. Elsevier Applied Science Publishers, London.

European Committee for Standardization. 2011. CSN EN 13039: Soil improvers and growing media. Determination of organic content and ash. CEN, Brussels, Belgium.

FAO. 2015. FAOSTAT. Online at: http://faostat3.fao.org/browse/Q/*/E, accessed 25 July 2015

Gajera, H. P., Bambharolia, R. P., Patel, S. V., Khatrani, T. J., and Goalkiya, B. A 2012. Antagonism of Trichoderma spp. against Macrophomina phaseolina: evaluation of coiling and cell wall degrading enzymatic activities. J. Plan Pathol. Microbiol. 3:149.

Green, R., and Papavizas, G. 1968. The effect of carbon source, carbon to nitrogen ratios and organic amendments on survival of propagules of Verticillium alboatrum in soil. Phytopathology 58:567-570.

Hadar, Y., and Papadopoulou, K. K. 2012. Suppressive composts: microbial ecology links between abiotic environments and healthy plants. Annu. Rev. Phytopathol. 50:133-153.

Handreck, K. A., and Black, N. D. 2002. Growing media for ornamental plants and turf. UNSW Press, Sydney, Australia.

Haran, S., Schickler, A., Oppenheim, A., and Chet, I. 1996. Differential expression of Trichoderma harizianum chitinases during mycoparasitisim. Phytopathology 86:980-985.

Harman, G., Hayes, C. K., Lorito, M., Broadway, R. M., Di Petro, A., Peterbauer, C., and Tronsmo, A. 1993. Chitinolytic enzymes of Trichoderma harzianum: purification of chitobiosidase and endochitinase. Mol. Plant Pathol. 83: 313-318

Harris, D. C., Yang, J. R., and Ridout, M. S. 1993. The detection and estimation of Verticillium dahliae in naturally infested soil. Plant Pathol. 42:238-250.

Hinz, P. N., and Eagles, H. A. 1976. Estimation of a transformation for the analysis of some agronomic and genetic experiments. Crop Sci. 16:280-283.

Hoitink, H. A. J., and Boehm, M. J. 1999. Biocontrol within the context of soil microbial communities: a substrate-dependent phenomenon. Annu. Rev. Phytopathol. 37:427-446.

Hoitink, H. A. J., Boehm, M. J., and Hadar, Y. 1993. Mechanisms of suppression of soilborne plant pathogens in compost-amended substrates. Pages 600-621 in: Science and Engineering of Composting. H. A. J. Hoitink and H. M. Keener, eds. Renaissance Publications, Worthington, $\mathrm{OH}$.

Inbar, J., and Chet, I. 1995. The role of recognition in the induction of specific chitinases during mycoparasitism by Trichoderma harzianum. Microbiology 141:2823-2829.

Inbar, Y., Boehm, M. J., and Hoitink, H. A. J. 1991. Hydrolysis of fluorescein diacetate in Sphagnum peat container media for predicting suppressiveness to damping-off caused by Pythium ultimum. Soil Biol. Biochem. 23:479-483.

Jiménez-Díaz, R. M., Cirulli, M., Bubici, G., Jiménez-Gasco, M. M., Antoniou, P. P., and Tjamos, E. C. 2012. Verticillium wilt, a major threat to olive production: Current status and future prospects for its management. Plant Dis. 96: 304-329.

Jones, J., Overman, A., and Geraldson, C. 1971. Fumigants for the control of Verticillium wilt of tomato. Plant Dis. Rep. 55:26-30.

Kaufman, Z., Nachmias, A., Livescu, L., Meiri, A., and Tibor, M. 1990 Verticillium wilt of potatoes under irrigation with saline water. Hassadeh 70 : 898-901.

Kennedy, A. 1999. Bacterial diversity in agroecosystems. Agric. Ecosyst. Environ. 74:65-76

Kinkel, L. L., Schlatter, D. C., Bakker, M. G., and Arenz, B. E. 2012. Streptomyces competition and co-evolution in relation to plant disease suppression. Res. Microbiol. 163:490-499.

Kokalis-Burelle, N., and Rodríguez-Kábana, R. 1994. Effects of pine bark extracts and pine bark powder on fungal pathogens, soil enzyme activity, and microbial populations. Biol. Control 4:269-276.

Larkin, R. P. 2015. Soil health paradigms and implications for disease management. Annu. Rev. Phytopathol. 53:199-221.

Larkin, R. P., Honeycutt, C. W., and Olanya, O. M. 2011. Management of Verticillium wilt of potato with disease-suppressive green manures and as affected by previous cropping history. Plant Dis. 95:568-576.

Levin, A. G., Lavee, S., and Lahkim, L. T. 2007. The influence of salinity on Verticillium dahliae in stem cuttings of five olive cultivars. J. Phytopathol. 155:587-592.

Lima, G., Piedimonte, D., De Curtis, F., Abobaker Elgelane, A., Nigro, F., D'Onghia, A. M., Alfano, G., and Ranalli, G. 2008. Suppressive effect of cured compost from olive oil by-products towards Verticillium dahliae and other fungal pathogens. Acta Hortic. 791:585-591. 
Litterick, A. M., Harrier, L., Wallace, P., Watson, C. A., and Wood, M. 2004. The role of uncomposted materials, composts, manures, and compost extracts in reducing pest and disease incidence and severity in sustainable temperate agricultural and horticultural crop production - A review. CRC. Crit. Rev. Plant Sci. 23:453-479.

López-Escudero, F. J., and Mercado-Blanco, J. 2011. Verticillium wilt of olive: A case study to implement an integrated strategy to control a soil-borne pathogen. Plant Soil 344:1-50.

Madi, L., Katan, T., Katan, J., and Henis, Y. 1997. Biological control of Sclerotium rolfsii and Verticillium dahliae by Talaromyces flavus is mediated by different mechanisms. Phytopathology 87:1054-1060.

Malandraki, I., Tjamos, S. E., Pantelides, I. S., and Paplomatas, E. J. 2008. Thermal inactivation of compost suppressiveness implicates possible biological factors in disease management. Biol. Control 44:180-187.

Markakis, E. A., Tjamos, S. E., Chatzipavlidis, I., Antoniou, P. P., and Paplomatas, E. J. 2008. Evaluation of compost amendments for control of vascular wilt diseases. J. Phytopathol. 156:622-627.

Ministerio de Agricultura Alimentación y Medio Ambiente. 2015. Anuario de Estadística 2014. Online: http://www.mapama.gob.es/estadistica/pags/anuario/ 2014/AE_2014_Completo.pdf (accessed 25 Jan 2016).

Ministerio de Medio Ambiente. 2007. Estudio de los Mercados del Compost. Memoria General. Online: http://www.juntadeandalucia.es/medioambiente/ planesmed/life/EstudioMercadoCompleto.pdf (accessed 25 Jan 2016).

Mohammadi, A. H., Banihashemi, Z., and Maftoun, M. 2007. Interaction between salinity stress and Verticillium wilt disease in three pistachio rootstocks in a calcareous soil. J. Plant Nutr. 30:241-252.

Monteiro, V. N., do Nascimento Silva, R., Steindorff, A. S., Costa, F. T., Noronha, E. F., Ricart, C. A. O., de Sousa, M. V., Vainstein, M. H., and Ulhoa, C. J. 2010. New insights in Trichoderma harzianum antagonism of fungal plant pathogens by secreted protein analysis. Curr. Microbiol. 61:298-305.

Moreno, M. T., Carmona, E., de Santiago, A., Ordovás, J., and Delgado, A. 2016. Olive husk compost improves the quality of intensively cultivated agricultural soils. Land Degrad. Dev. 27:449-459.

Morillo, J. A., Antizar-Ladislao, B., Monteoliva-Sánchez, M., Ramos-Cormenzana, A., and Russell, N. J. 2009. Bioremediation and biovalorisation of olive-mill wastes. Appl. Microbiol. Biotechnol. 82:25-39.

Nguyen, N. V., Kim, Y. Y., Oh, K. T., Jung, W. J., and Park, R. D. 2008. Antifungal activity of chitinases from Trichoderma aureoviride DY-59 and Rhizopus microsporus VS-9. Curr. Microbiol. 56:28-32.

Noble, R., and Coventry, E. 2005. Suppression of soil-borne plant diseases with composts: A review. Biocontrol Sci. Technol. 15:3-20.

Noble, R., and Roberts, S. J. 2004. Eradication of plant pathogens and nematodes during composting: A review. Plant Pathol. 53:548-568.

O'Brien, M., and Colwell, R. R. 1987. A rapid test for chitinase activity that uses 4methylumbelliferyl-N-acetyl-beta-D-glucosaminide. Appl. Environ. Microbiol. 53:1718-1720.

Ochiai, N., Powelson, M. L., Crowe, F. J., and Dick, R. P. 2008. Green manure effects on soil quality in relation to suppression of Verticillium wilt of potatoes. Biol. Fertil. Soils 44:1013-1023.

Ortega, M. C., Moreno, M. T., Ordovás, J., and Aguado, M. T. 1996. Behaviour of different horticultural species in phytotoxicity bioassays of bark substrates. Sci. Hortic. (Amsterdam) 66:125-132.

Papasotiriou, F. G., Varypatakis, K. G., Christofi, N., Tjamos, S. E., and Paplomatas, E. J. 2013. Olive mill wastes: A source of resistance for plants against Verticillium dahliae and a reservoir of biocontrol agents. Biol. Control 67:51-60.

Pascual, I., Azcona, I., Morales, F., and Aguirreolea, J. 2009. Growth, yield and physiology of Verticillium -inoculated pepper plants treated with ATAD and composted sewage sludge. Plant Soil 319:291-306.

Principi, P., Zucchi, M., Ranalli, G., Zanardini, E., and Sorlini, C. 2001. Microbiological monitoring of olive husk composting. Pages 405-410 in: Proceedings of the International Conference Orbit 2001 on Biological Processing of Waste: A Product Oriented Perspective. 9-12 May 2001, Seville, Spain.

Ranalli, G., Bottura, G., Taddei, P., Garavani, M., Marchetti, R., and Sorlini, C. 2001. Composting of solid and sludge residues from agricultural and food industries. Bioindicators of monitoring and compost maturity. J. Environ. Sci. Heal. Part A 36:415-436.
Recena, R., Torrent, J., del Campillo, M. C., and Delgado, A. 2015. Accuracy of Olsen $\mathrm{P}$ to assess plant $\mathrm{P}$ uptake in relation to soil properties and $\mathrm{P}$ forms. Agron. Sustain. Dev. 35:1571-1579.

Saadatmand, A., Banihashemi, Z., Sepaskhah, A., and Maftoun, M. 2008. Soil salinity and water stress and their effect on susceptibility to Verticillium wilt disease, ion composition and growth of pistachio. J. Phytopathol. 156:287-292.

Saadi, I., Laor, Y., Medina, S., Krassnovsky, A., and Raviv, M. 2010. Compost suppressiveness against Fusarium oxysporum was not reduced after one-year storage under various moisture and temperature conditions. Soil Biol. Biochem. 42:626-634.

Saison, C., Degrange, V., Oliver, R., Millard, P., Commeaux, C., Montange, D., and Le Roux, X. 2006. Alteration and resilience of the soil microbial community following compost amendment: Effects of compost level and compost-borne microbial community. Environ. Microbiol. 8:247-257.

Selim, S. M., Zayed, M. S., and Houssam, M. A. 2012. Evaluation of phytotoxicity of compost during composting process. Nat. Sci. 10:69-77.

Shahidi Bonjar, G. H., and Aghighi, S. 2005. Chitinolytic and microsclerostatic activity of Iranian strains of Streptomyces plicatus and Frankia sp. on olive isolate of Verticillium dahliae. Biotechnology 4:108-113.

Shao, F., and Foy, C. 1982. Interaction of soil manganese and reaction of cotton to Verticillium wilt and Rhizoctonia root rot. Commun. Soil Sci. Plant Anal. 13: 21-38.

Stone, A., Scheuerell, S., and Darby, H. 2004. Suppression of soilborne diseases in field agricultural systems: Organic matter management, cover cropping, and other cultural practices. Pages 131-177 in: Soil Organic Matter in Sustainable Agriculture. F.Magdoff and R. R. Weil, eds. CRC Press, Boca Raton, FL.

Stone, A. G., Traina, S. J., and Hoitink, H. A. J. 2001. Particulate organic matter composition and Pythium damping-off of cucumber. Soil Sci. Soc. Am. J. 65:761-770.

Sullivan, D. M., and Miller, R. O. 2001. Compost quality attributes, measurements, and variability. Pages 95-120 in: Compost Utilization in Horticultural Cropping Systems. P. Stoffella and B. A. Kahn, eds. CRC Press, Boca Raton, FL.

Termorshuizen, A. J., and Jeger, M. J. 2008. Strategies of soilborne plant pathogenic fungi in relation to disease suppression. Fungal Ecol. 1:108-114.

Termorshuizen, A. J., van Rijn, E., van der Gaag, D. J., Alabouvette, C., Chen, Y., Lagerlöf, J., Malandrakis, A. A., Paplomatas, E. J., Rämert, B., Ryckeboer, J. Steinberg, C., and Zmora-Nahum, S. 2006. Suppressiveness of 18 composts against 7 pathosystems: Variability in pathogen response. Soil Biol. Biochem. 38:2461-2477.

Trillas, M. I., Casanova, E., Cotxarrera, L., Ordovás, J., Borrero, C., and Avilés, M. 2006. Composts from agricultural waste and the Trichoderma asperellum strain T-34 suppress Rhizoctonia solani in cucumber seedlings. Biol. Control 39: 32-38.

Tuitert, G., Szczech, M., and Bollen, G. J. 1998. Suppression of Rhizoctonia solani in potting mixtures amended with compost made from organic household waste. Phytopathology 88:764-773.

van Bruggen, A. H. C., and Semenov, A. M. 2000. In search of biologica indicators for soil health and disease suppression. Appl. Soil Ecol. 15:13-24.

Vitullo, D., Altieri, R., Esposito, A., Nigro, F., Ferrara, M., Alfano, G., Ranalli, G. De Cicco, V., and Lima, G. 2013. Suppressive biomasses and antagonist bacteria for an eco-compatible control of Verticillium dahliae on nurserygrown olive plants. Int. J. Environ. Sci. Technol. 10:209-220.

Weller, D. M., Raaijmakers, J. M., Gardener, B. B. M., and Thomashow, L. S. 2002. Microbial populations responsible for specific soil suppressiveness to plant pathogens. Annu. Rev. Phytopathol. 40:309-348.

Xue, L., Xue, Q., Chen, Q., Lin, C., Shen, G., and Zhao, J. 2013. Isolation and evaluation of rhizosphere actinomycetes with potential application for biocontrol of Verticillium wilt of cotton. Crop Prot. 43:231-240.

Yildiz, A., and Benlioglu, S. 2010. Effects of soil solarization and some amendments to control Verticillium wilt in established olive orchards. Afr. J. Biotechnol. 9:6660-6665.

Zak, J. C., Willig, M. R., Moorhead, D. L., and Wildman, H. G. 1994. Functional diversity of microbial communities: a quantitative approach. Soil Biol. Biochem. 26:1101-1108.

Zucconi, F., Monaco, A., Forte, M., and de Bertoldi, M. 1985. Phytotoxins during the stabilization of organic matter. Pages 73-88 in: Composting of Agricultural and Other Wastes. Gasser J. K. R., ed. Elsevier Applied Science, London and New York. 